Festival Mania, Tourism and Nation

Building in Fiji: The Case of the

Hibiscus Festival, I956-1970

Claus Bossen

To ourism development has important and complex effects on the formation of identity. As a potential threat to the authenticity or integrity of local cultures, tourism's relation to cultural, ethnic, and national identities has been and remains controversial. Unequal power relations are a crucial factor, and the mix of constraints and opportunities tourism entails often favors the projects of states and industry, but it may also enable local groups to pursue theirs. I argue that, in Fiji, the Hibiscus Festival, which is staged annually in Suva, the capital, has interwoven international tourism and national identity in such a way that cultural and national identities are reinforced in counterpoint with wider political and social changes. The I950s and I960s were decades of change that profoundly transformed the British colonial order in Fiji. Global growth in international tourism made Fiji a tourist destination, while political developments brought nation building and democratic government to the forefront, resulting in the independent state of Fiji in 1970. From its inception in I956 to Fiji's independence in I970, the Hibiscus Festival contributed to the process of nation building, created a positive attitude toward tourism in the populace, and fused these into an appearance of public harmony.

After the Second World War, cruise liners resumed their voyages from the Americas to Australia and the Far East and began to make calls at Suva, once again bringing tourists to the city. International flights also brought visitors to Fiji and contributed to a boom in the country's tourist industry as they increasingly used the airport at Nadi as a refuelling point when crossing the Pacific. Tourism was promoted by local European business interests and the government, for whom it was an alternative to

The Contemporary Pacific, Volume I2, Number I, Spring 2000, I23-I54

(C) 2000 by University of Hawai'i Press 
the sugar industry; though still the backbone of the economy, sugar had limited growth potential (Britton I983, 9-3I). At the same time, as more and more colonies in Africa and Asia became independent, the United Nations put pressure on the colonial powers to decolonize. In Fiji, which became a British colony in 1874 , the two main ethnic groups ${ }^{1}$ were indigenous Fijians and the descendants of Indian immigrants (from here on referred to as Indo-Fijians), each of which made up around 45 percent of the population. Until independence, the two groups had lived relatively separately under a stable British order based on divide-and-rule. The 1946 census revealed that the Indo-Fijians had surpassed the indigenous Fijians in numbers during the war, triggering a heated debate on the status of the two groups and on the system of government. Indigenous Fijians and Europeans were not interested in changing the status quo, which gave them both privileged positions within the state, while the Indo-Fijians pressed for independence and a universal electoral roll. Questions that arose included how all ethnic groups could live side by side as parts of the same state, and whether a common national identity was possible. Could colonial Fiji become a nation?

\section{The Hibiscus Festival}

The Hibiscus Festival was started in 1956 by the Suva branch of the Junior Chamber of Commerce (abbreviated to JCC and hence also called the Jaycees). This international association (with local branches in more than 50 countries and more than 500,000 members) aimed to foster interest in civic pride and progress, and was "essentially a constructive organization of young men who devote a portion of their time to community service in the public interest, thereby providing opportunities for development in leadership amongst its members" (Fiji Times, I9 Oct I954). ${ }^{2}$ In 1956, its elected board was composed mainly of Europeans, but also included Indo-Fijians and indigenous Fijians. Among the board members then and in later years were business managers from trade, tourism, and banking as well as government employees from broadcasting, printing, and the Fiji Visitors Bureau.

Inspiration for the festival came from a local tour operator who had seen the Aloha Festival in Hawai'i, and whose report on his experiences induced the Suva Jaycees to stage a similar festival. The Aloha Festival had been started by the local tourist bureau and the Hawai'i Jaycees 
chapter, both of which wished to prolong the tourist season; it had proved so successful that the low season was turned into a high season. The Jaycees in Suva hoped for a similar success and staged the first festival in December 1956, with the dual aims of providing a time of fun for people in Suva and attracting tourists to the city.

The first Hibiscus Festival in 1956 lasted two days and reached its climax on the second day with a procession of floats through the streets of central Suva and the crowning of a Miss Hibiscus. Twenty-two young women competed for this title and were judged on two public events by a panel of judges, according to dress sense, physical beauty, deportment, personality, and conversation (Fiji Times, I2, I3, I4 Dec I956). The first festival was backed by Governor Sir Ronald Garvey and the mayor of Suva, and in the following years the festival was extended to last three days in 1957, four days in 1958, and from 1960 onward it lasted eight days, opening and closing on Saturdays. By then the program included both a Fijian and an Indian night, which gave the two largest ethnic groups an opportunity to present themselves to an audience of locals and tourists. Within four years the festival had come to be regarded as a permanent highlight in the Fiji calendar and a success in terms of both local support and attracting tourists.

By I960, the festival had developed a pattern of events that was to continue almost unchanged until today. The festival would be opened by a "March of Youth," in which Boy Scouts, Girl Guides, and various other youth organizations paraded through the streets of central Suva. The procession would be led by the Fiji Military Forces Band or the Fiji Police Band and by several marching girls teams, which had been formed after I958, when a New Zealand marching girls team participated in the festival. The procession, which in the early I96os numbered up to three thousand youths, would go to Albert Park and be on parade for the opening ceremony: the mayor of Suva would make a speech, followed by scouts' display or sports competition. Albert Park lies just opposite the grand old lady of Fiji tourism, the Grand Pacific Hotel, and is also used for state ceremonies.

During the festival, however, Albert Park was full of stalls with foods and soft drinks, a Ferris wheel, merry-go-rounds, and other entertainments, and around the town center a variety of events were held, including baby shows, philatelic exhibitions, fashion shows, casino nights, revues, and so forth. Permanent features, however, were the ethnic nights, 
where indigenous Fijians, Indo-Fijians, Chinese, and sometimes Pacific Islanders each on their own night would perform dances and singing. Though mixed, the audience, which could number up to five thousand people, would usually be dominated by individuals from the ethnic group on stage. Another permanent element from 1956 onward was the Miss Hibiscus contest, where entrants would appear for two, sometimes three, "public judgings" and one "private judging." In the public event the contestants would appear on stage, answer questions, and be judged on physical beauty, deportment, and dress sense by a panel of "good citizens" nominated by the organizers of the festival. Later in the week the judges would converse with the contestants at a private judging, where the focus would be on their general knowledge, personality, and ability to represent Fiji overseas.

The climax of the festival would be a procession of floats through central Suva. Each contestant in the Miss Hibiscus contest would usually have her own float, and as well, firms and organizations that did not sponsor a contestant would enter floats: giant telephones, huge globes, and enormous toads would roll through the streets to Albert Park. Here Miss Hibiscus would be crowned, usually by the governor, a Fijian high chief, or a government minister. A ball at the Grand Pacific Hotel would end the festival for Miss Hibiscus and local dignitaries, while crowds of people were enjoying the last rides on merry-go-rounds or the Ferris wheel or having a final try in games of chance.

Inspired by the Hibiscus Festival, similar festivals were organized in other towns of Fiji. In Lautoka, the second biggest town in Fiji, a chapter of the Jaycees had been formed in 1957, and in 1961 they organized a festival in connection with the Cession Day celebrations (discussed later), crowned their Miss Sugar, and thus started what became the Sugar Festival the following year. Also in I96I, the Chamber of Commerce in Nadi, next to the international airport, organized a "Nadi Commerce Week," which in the following year became the Bula Festival, at which Miss Bula was crowned. During the I960s, similar festivals were started in Ba, Savusavu, Labasa, Kadavu, Taveuni, and Sigatoka, and all followed the pattern of events set by the Hibiscus Festival. A new aim was added to the festivals in these towns, in that any profits were to be given to charity. A Charity Queen contest was held in $\mathrm{Ba}$ in I962, crowning the contestant who, during the festival, raised the most money for charity. Nadi had its Charity Queen in 1963, Lautoka had one in 1965, and the 
Hibiscus Festival finally followed the others in 1967 by crowning its own Charity Queen, though a Charity Chest had been started a few years before, financed by any profits that exceeded calculated expenses for the next festival.

The raising of money for charity in the Charity Queen contest added a fourth aim to the festival, in addition to providing entertainment for Suva's citizens, attracting tourists, and crowning a Miss Hibiscus, though the Miss Hibiscus contest remains the central event. As her main prize, Miss Hibiscus gets a trip to one of Fiji's foremost tourist-supplying countries-Australia, New Zealand, Canada, Japan, or the United States. On her journey, she is regarded as an unofficial ambassador for Fiji and is expected to promote tourism to her country; often, her travel arrangements are coordinated with promotional campaigns of the Fiji Visitors Bureau.

Already in 1957, tourists were attending the Hibiscus Festival, and over the following years cruise liners began to schedule their arrivals to coincide with it. Besides the local support in Suva and in Fiji generally, the festival began to be a tourist attraction not only in name but also by right.

\section{INTERnATIONAL TOURISM AND National IDENTITY}

Like other industries, the tourist industry demands favorable conditions for investments, provision of infrastructure and land, and the availability of qualified labor. It has, however, two special characteristics. First, international tourism often means that cultural difference is part of the attraction and that cultural items are at the center of the "tourist gaze" (Urry I990). Second, the tourist product is consumed at the place where it is produced, so the demands of the consumer for the product affect both the process and the place of production (Urry I990). Not only food and lodging, but also surrounding areas and towns, local people, and the image of the country have to satisfy the culturally based expectations of the tourists. The country as a whole and its population become part of the tourist product. ${ }^{3}$ Because of these characteristics, discussions of tourism often focus on the potential dangers of commercialization and inauthenticity of cultural items that become "pseudo-events" (Boorstin I96I) or manifestations of "staged authenticity" (MacCannell I973; I976). ${ }^{4}$ The effects of tourism, however, vary with the type of tourism (eg, mass or elite tourism, leisure or culture tourism; Cohen I972; Smith I978) and 
are mitigated by the ability to satisfy tourists' demands in a number of ways. For example, the desire for exoticness may be met by a wide range of cultures, as long as they differ sufficiently from the tourists' own.

The two special characteristics of tourism have meant that considerable attention has been given to the potential conflict between tourism and cultural identity. ${ }^{5}$ Most anthropological work on tourism centers on single cultural elements like ritual, dances, and souvenirs (Graburn 1976), on ethnic groups (Smith 1978), or on the direct interaction between tourists and locals (Nettekoven 1979; Smith 1978). Few have considered the implications of tourism for nation building and the generation of national identity. One of the first to do so was Frank Manning, who summarized the problem of tourism and national identity by saying, "decolonization and tourist development have antithetical implications. The movement toward political sovereignty inspires cultural pride and national self-esteem. Reliance on an economic system based on capital, management, and clientele coming chiefly from white metropolitan countries has the opposite effect" (I978, I98).

To any state engaged in nation building, international tourism adds a new factor, because the industry implies an "expanded cultural role" for the state (Wood I980; 1984). Choosing which part of the national heritage should be marketed is simultaneously a statement on national identity, and, in order to provide a suitable environment for tourists, the state has to adjust and control the public arena, for example through Keep Smiling campaigns. The state may furthermore become organizer of cultural reproductions (eg, museums, national parks, cultural centers) and the licensing authority concerning the authenticity and quality of products sold to tourists. Finally, the state may become arbiter of conflicts between ethnic groups that compete with each other and the state for access to the opportunities provided by tourism (Wood I980, 569-572; I984, 365-370). Similarities between the state and the tourist industry are found in at least three areas: both aim at increased turnovers, both want to emphasize the uniqueness of a place (eg, the territorialized nation), and both effectuate objectification of culture. Even though the international tourist industry is characterized by highly unequal economic relations, it does not by necessity have "antithetical implications" for nation-states.

After the pioneering articles by Manning (I978) and Wood (I980), few addressed the question of international tourism and nation building. From the early I990s, however, several contributions have been made that, though there is no unified approach, highlight the complex ways in which 
ethnicity, nation building, and tourism may intersect. ${ }^{6}$ Of special regional interest here is the contribution of Jeffrey Sissons, who has argued that since the opening of an international airport in I973 ("DC8 Day"), the Cook Islands has increasingly positioned itself at an international intersection through which flows a traffic of people, capital, and ideas. "In the midst of all this a new sense of nationhood is emerging; a sense of living in an increasingly commodified space, of belonging to an imagined community for others-a tourist stopover, a desti-nation" (I997, I 86).

The creation of nationhood in the Cook Islands, as both a state project and a less-conscious process of identity formation, according to Sissons, has shifted from DC8 Day, with an emphasis on progress and togetherness in a project of modernization, to a project of cultural nation building, where internal cultural differences have become blurred in the process of marketing the nation as Polynesian. While the condition of being a destination in one perspective seems like disneyfication, Sissons argued, from another perspective it can be seen as an incentive for local differentiation, for new forms of community participation and new forums for political debate (1997, I 87). ${ }^{7}$ Thus, for example, the professionalization of dance troupes through tourism has encouraged diversity and local distinctiveness rather than togetherness and modern order. Otto and Verloop argued that because of the international attention through tourism to the dance and masks of the Asaro Mudmen, these are strong contenders for becoming national symbols in Papua New Guinea (I996).

\section{National IDENTity}

The projects of nation building of states take place at the intersection of the international political system, which makes the nation-state a norm, and the national arena in which governments have to legitimize themselves as representatives of all citizens within the state. The paradox of the nation is that it is an international ideology imported for national ends (Löfgren I989, 8). The "imagined community" (Anderson I99I) of the nation is always constructed in a process of identification where a self is defined in contrast to external or internal others (the nation in contrast to other nations, or the nation in contrast to marginal groups within the state's borders). In the newly independent states of the South Pacific, concepts of Melanesian Way, the Pacific Way, or kastom are evoked in opposition to the West and the modern. ${ }^{8}$ Nation building may be based on a strategy of purification, where homogeneity is to be created out of exist- 
ing heterogeneity: one culture becomes the norm, and divergent identities are defined as "ethnic," implying that they are marginal to the core national identity (Williams I989). Purification, however, is seldom totally successful, and several situations may arise: first, the national identity may remain contested as two or more groups fight to define it; second, the national identity may revolve around formal symbols, events, or concepts that have no specific ethnic associations (eg, multiculturalism); finally, where nation building does not come off the ground, the concept of nation is fragile and flimsy (for Melanesia see Foster I995a; Otto and Thomas 1997). On its way toward independence in I970, Fiji oscillated between all of these possibilities.

The history of the state of Fiji since I 874 provides a frame of reference for all its citizens, but evaluations of large parts of the history are not shared by the indigenous Fijians and the Indo-Fijians because the divideand-rule politics of the British colonial government positioned them separately and with generally conflicting interests. After a group of chiefs ceded sovereignty to Queen Victoria in I874, a special Fijian Administration was established that confined the indigenes to subsistence farming and established a neotraditional hierarchy of chiefs through which they were ruled. To get the economy going, the colonial government invited the Australian-based Colonial Sugar Refining Company to establish a sugar industry, and imported sixty thousand laborers from India between I 897 and I920. Colonial policies caused cultural differences between the indigenes and the immigrants to become social and political differences as well. Interaction between the two groups was inhibited, and political influence was granted gradually-along communal lines. The major point of conflict was and is access to land: 83 percent of the land is owned by indigenous Fijians, and because many Indo-Fijians gain their livelihood by growing sugar cane, the terms for lease of land have been a recurrent point of contention. Politically, indigenous Fijians, Indo-Fijians, and Europeans all had their claims to the state of Fiji. To the indigenous Fijians, the Deed of Cession was central: it was conceived as the establishment of a special linkage between British and indigenous Fijian royalty and also as giving indigenous Fijians paramountcy of interest because it recognized their rights, though in unspecified terms. ${ }^{9}$ To Indo-Fijians on the other hand, the Salisbury Despatch, in which Lord Salisbury as secretary of state for the colonies in 1875 stated that Indian immigrants should have "privileges no whit inferior" to other residents in the colonies, was central. Last, Europeans claimed, on account of their race and civilization 
and as representatives of the British empire, to have a privileged position. Reconciling these incompatible interests-paramountcy of indigenous Fijians, parity for Indo-Fijians, and special privileges for Europeansbecame a main problem for the colonial government after the Second World War.

Encouraged by the independence of India in 1947 and the pressure toward decolonization by the United nations, Indo-Fijians demanded an end to colonial rule and the introduction of a universal electoral roll. As the Indo-Fijians were in the majority, this conception of the nation in terms of citizenship was resisted emphatically by indigenous Fijians, who feared becoming a minority, and by the Europeans, who saw an alliance with indigenous Fijians as a way of maintaining their privileged position within the state. From this point of view, the Deed of Cession established the nation as based on indigenous Fijian ethnicity with European assistance. Maneuvering between the Deed of Cession and the Salisbury Despatch, neither the claim for "Fiji for Fijians" nor the demand for a universal electoral roll was a feasible option for the colonial government.

Navigating through the political waters, mutual understanding, harmony, interracialism, and later multiculturalism became guiding concepts in the colonial view of the nation. These concepts made it possible for the colonial government to sustain different narratives of the nation. It recognized and upheld ethnic divisions against the notion of one-nation inherent in claims for a universal electoral roll, and at the same time left the relations between the groups unspecified. Were all groups equal, or were, as in practice, "Fijians" as an indigenous group more equal than other groups that were merely "ethnic"? Political participation was slowly granted in the I950s and I960s along with communal rolls, and the constitution of independent Fiji in 1970 provided indigenous Fijians and Indo-Fijians an equal number of seats in the Parliament, yet also introduced a Senate in which indigenous Fijians could veto any legislation that was seen to threaten indigenous Fijian culture and traditions.

The creation of nationhood, however, may be pursued not only as a conscious project of formation of national identity by agents, such as elites dominating the state. Nationhood might also result from movements and practices occurring in civil society, which is here taken to designate that part of public life which is not under the direct influence of the state. In this connection, E H Eriksen made a useful distinction between formal nationalism and informal nationalism: "Formal nationalism is connected with the demands of the modern nation-state, including bureaucratic 
organization and meritocratic ideology, cultural uniformity and political consensus among the inhabitants. Informal nationalism is identified in collective events, such as ritual celebrations and international sports competitions, taking place in civil society" ( $1993, \mathrm{I})$.

The intention is not to depict the relation between the two forms of nationalism as a fundamental cultural opposition that illustrates the impersonal power of the state confronting the personal power of civil society. Rather, they are complementary aspects, and for nationalism to be successful they have to become interlocked. Though Eriksen wrote about Mauritius, his example is easily generalized:

The ideological rhetoric surrounding Mauritian industrialization is a good example of this. While formal aspects of industrialization as nationalism include the improvement of the national trade balance and the cultural homogenization of the population, it presents itself to Mauritians as a means to improve their material standard of living, and to many Mauritian women as a way of achieving personal independence. Only when the two nationalisms interlock in such a way can a state nationalism be truly efficient. (Eriksen I993, I 8)

In a similar vein, $\mathrm{R} J$ Foster, for example, showed how consumption of goods in Papua New Guinea may be framed as a particular PNG practice (1995b; see also Thomas I997). I argue that the Hibiscus Festival is a collective event taking place in civil society and has contributed to the generation of an informal national identity that overlaps the formal nationalism of the government. As theories on ritual and public events explain, rituals derive their efficacy through the connection of symbols with sentiments aroused through ritual enactment. The enjoyment by all ethnic groups in Fiji of the events of the Hibiscus Festival was put into an interpretational frame of multiculturalism by its organizers and by leading people in society and thus interlocked with the colonial government's attempts to make Fiji a nation and not just a colony.

That the festival was devised around a beauty contest is significant. The modern beauty contest is an American invention of the I85os (Banner I983), and has, especially since the Second World War, spread all over the world (Cohen, Wilk, and Stoeltje 1996). The beauty contest can, in ways similar to B Anderson's imagined nation (I99I), be seen as a modular form, constituted at the intersection of the national and the international, and open for piracy (Wilk I996). Many organizers deny that their queen rallies are beauty contests, often pointing out that the contestants 
do not appear in swimsuits, while critics declare that because the form is that of the beauty contest, this is what they are (see Lavenda I996). Whether or not the Miss Hibiscus contest is a beauty contest is similarly argued in Fiji. In 1966, when plans for a Miss Fiji contest were launched in order to produce a winner suitable to enter regional beauty contests, the initiative was welcomed by the then president of the Hibiscus Festival Association (and chairman of the Fiji Visitors Bureau) as the Miss Hibiscus contest was not a beauty contest (Fiji Times, 2I Nov 1966). Yet, no matter which, the Miss Hibiscus contest provided a way for Fiji to make itself visible in the international arena.

\section{Changes in Fiji after the Second World War}

The emergence and success of the Hibiscus Festival was closely connected with changes taking place in Fiji in the I950s and I960s. Migration from the countryside to the towns, and especially to the city of Suva, a gradual dissolving of racial barriers in public life, political changes that first provided elected seats in city councils and the Legislative Council and then led toward independence, and the growth of tourism created a new public space in the urban centers of Fiji.

Until the Second World War indigenous Fijians and Indo-Fijians had to large extent lived separately: the indigenous Fijians were subsistencefarmers living in villages; the Indo-Fijians were sugar-cane growers living on individual plots of land; and the Europeans were planters, businesspeople, or administrators living in the towns. Though towns like Suva were multiethnic, social life was compartmentalized (see Mamak I978, 26; Lal 1992, I06-107). After the war, public life was increasingly less segregated along ethnic lines. For example, the first recreational club encompassing all ethnic groups was founded in 1945, and in 1956 the Suva Sea Baths were opened to indigenous Fijians and Indo-Fijians. Among the urban middle class, interracial ties were cultivated in clubs and in sports, though on asymmetrical terms: Europeans and indigenous Fijians were usually the patrons, while Indo-Fijians were their clients. The very depth of the divisions in culture and society paradoxically favored a certain intensity in these interracial associations: a vigorous affirmation of friendly accord despite the differences. The colonial officials encouraged this disposition by emphasizing both the strength of the racial division and the need to bridge it (Norton I990, 54).

On a broader scale, migration to the towns created a public arena 
where interethnic meetings and interactions were more frequent. Notably, the population of Suva grew from 25,000 to 37,000 between I 946 and I956. An "information revolution" took place (Lal I992, I 52), with the extension of broadcasting and the proliferation of local newspapers besides the largest and only daily newspaper, the Fiji Times, so that by the late I950s Fiji had eleven newspapers. The main challenge to the Fiji Times' procolonial coverage was the Pacific Review, started in I949 by A D Patel, a prominent leader of the Indo-Fijians. Political life was opened, and debates were accelerated by changes in the council of Suva in 1949 and I961 and at national level in 1963, when indigenous Fijians and women could vote in the general elections for the first time (see Qalo I984; Lal I992, I64-213).

The result of these processes of change was the creation of a new urban public sphere in which official ethnic segregation was dissolving, interethnic meetings were more frequent, and public debate became more open. The colonial order was changing, and a central question was how people were now to live together in the same state.

\section{International Tourism in the New Urban Sphere}

Although these changes were important preconditions for the advent of the Hibiscus Festival, the main reason for it was the growth of international tourism to Fiji in general and Suva in particular. As stated earlier, cruise liners began to arrive in Suva with greater frequency, and international flights to Fiji increased in the r950s. The government did not become seriously interested in tourism before the late I950s, when tax concessions for hotel investments were given (1958) and duty-free shopping was introduced (1962). However, the Fiji Visitors Bureau, founded in 1923 , was very active in the promotion of the industry and organized, for example, the first tourist conference in 1952. Apart from promoting Fiji overseas, the bureau also tried to monitor and regulate the public through Keep Smiling campaigns and a model village competition. The efforts of the bureau were supported by the Fiji Times, which was an avid promoter of tourism to Fiji. The paper deplored "the apparent lack of interest in its value as a tourist resort by Fiji itself" (28 Jan 1950) and urged the public to develop a civic pride that would make people interested in the beautification of the city: to have a well-ordered, clean and pleasant city was, to the Fiji Times, a matter of both self-respect and of being presentable to tourists. ${ }^{10}$ The Suva City Council launched annual 
clean-up campaigns, and the visit of the newly crowned Queen Elizabeth II in I953 was taken as a special opportunity to further civic pride.

The tourist industry in Fiji in the early I950s consisted of a few local pioneers. As tourism grew, foreign capital and local Europeans came to dominate the industry, and the Europeans became a group with intimate knowledge about tourism in Fiji and close links to the government (Britton I983). In I953 one pioneer opened the Korolevu Hotel, which provided accommodation for cruise-line passengers who wanted to have a night or two on land. He expanded his business to a chain of hotels, simultaneously being a member of the Legislative Council and codirector of the Fiji Times. Another pioneer was the European tour operator whose report on the Aloha Festival inspired the Jaycees to start the Hibiscus Festival. In 1947 he had, with his wife, started a tour company that employed and sponsored Miss Hibiscus 1957. Furthermore, he was a member of the Suva City Council from 1959 to 1968, mayor of Suva in 1967, and vice president and president of the Hibiscus Festival Association from I96I to I964. In I97I he bought an Australian tour company and sponsored another employee to become Nadi's Bula Queen. Of all enterprises in I977, 42 European firms accounted for I 5 percent of the total turnover, while 324 Indo-Fijian, 395 indigenous Fijian, and 25 "Other" enterprises accounted for I 5 percent, I percent, and 4 percent of the total turnover respectively. Notably, 38 foreign enterprises accounted for the remaining 66 percent of turnover (Britton I983, I87).

The tourist industry, the Fiji Visitors Bureau, and the Fiji Times all sought to achieve a positive attitude toward tourism and to encourage civic pride, which had at its center courtesy to tourists, beautification, and pride in the city of Suva. They all had an economic interest in the growth of tourism, and their positions of power and means to enact policy could justifiably be directed toward these ends. Notably, they were dominated by Europeans, some of whom were simultaneously members of the Suva City Council or the Legislative Council. Though they did not form an undivided front, this group of Europeans had ample opportunity to influence public life and opinion. This also implies a systematic effect on the information on which this account is built (see note 3 ), and it should be borne in mind that the main focus here is on the dominant representation of the festival and its connection to the government's imagining of the nation. On the other hand, the festival's persistence, the size of audiences in the I950s and I960s, and its reliance on civil support make it more than just an invention of the powerful. ${ }^{11}$ 
See Fiji And Live!

One concern in the promotion of tourism to Fiji was the realization that the tourists, apart from transport, accommodation, and food, also needed something to do. In the aftermath of spectacular events in the early I950s, Suva had come to be perceived as a boring and dull place, according to the Fiji Times: at the coronation of Queen Elizabeth II in London, grand celebrations were held in Suva and elsewhere in Fiji, and public ceremonies surrounded her visit to Fiji in 1953. In 1954, fund-raising for gifts to the indigenous Fijian soldiers fighting in Malaya was organized around a charity queen competition with the crowning of a queen in Suva as the climax. Immediately after, a public Christmas tree celebration was proposed in a letter to the Fiji Times, which took up the matter in its editorial: "The Coronation celebrations, the Royal visit decorations and lights, and the brief flicker for the queen-crowning evening last month have had the cumulative effect of emphasising the habitual drabness of most of central Suva. Every year other cities overseas, from London downwards, break into a rash of lighted Christmas trees in December and there seems to be no reason-barring the expense-why Suva should not do something on a very small scale" (Fiji Times, 8 Oct I954). The following day the newspaper could report that the governor had already conceived such an idea, and "Carols-by-Candlelight" was held on 22 December 1954 with the governor present. The perception of Suva as a drab place was not alleviated, however, and the Fiji Times suggested a "South Seas Exhibition annually which would become a mecca for tourists as well as a demonstration of our skills and production. An annual Fiji Festival-how does that sound? . . 'See Naples and Die' is depressing, compared with 'See Fiji and Live!'” (Fiji Times, I 8 May 1955).

Again and again, the Fiji Times called for an annual festival to be organized, linking the issue with tourism. ${ }^{12}$ In April 1956 , island traditions of hospitality, friendly people, and South Pacific scenery were not considered enough to promote tourism:

We cannot build up a tourist trade on palm trees against the sunset, "sunny Fiji" propaganda and Isa Lei [an indigenous Fijian, popular song] alone, fascinating although all these things may be. We've got to give people something to do when they get here in the shape of absorbing participant and spectator sports, carnivals and festival of fun, frolic, art and music. ... Selling atmosphere, particularly of romance and fostering adventure in the copra laden 
tradewinds, is good business. But - give them something to do when you get them here. That would be even better business. (Fiji Times, 2 Apr 1956; my insertion)

Nothing eventuated, however, until in May I956 the Fiji Visitors Bureau suggested an annual festival to be organized in order to preserve, in the bureau's wording, "ancient" (indigenous Fijian) traditions and arts, and to attract people to Fiji. It was mainly to be a tourist attraction, could have shows of the different ethnic groups in the colony, should last one week ending at Cession Day, and might, all in all, boost what was now a "dead" tourist season (Fiji Visitors Bureau according to Fiji Times, 23 May I956). The Fiji Times immediately supported the idea and-finally -in September the Suva Junior Chamber of Commerce, which had been formed in June, announced that it would organize a festival in Suva in December. A spokesman for the Suva Junior Chamber of Commerce said that "the Chamber felt that Suva should have an annual festival of carnival, culture and sport so as to promote civil goodwill, maintain the high standards of local industry and traditional gaiety. The Festival would also attract tourists and would advertise Fiji throughout the world" (Fiji Times, 29 Sept 1956).

The Hibiscus Festival evoked wide public interest and received support from various sides. At the first festival in 1956, the organizers appealed for people to wear bula shirts (brightly colored shirts, often with flower patterns) while at work, which was staunchly prohibited by heads of government departments. The festival, however, received the unofficial blessing of the governor, when he appeared at the festivities wearing a bula shirt and a spray-painted pith-helmet. The Suva City Council made Albert Park and electricity available free from 1957 onward, and the Fiji Visitors Bureau marketed the festival overseas. A Hibiscus Festival Association was formed in 1960, and at its request the Fiji Visitors Bureau took responsibility for organizing the festival from I960 to I965. The personal interrelations between the festival association and the Fiji Visitors Bureau were close: the secretary of the bureau from 1953 to 1958 was on the organizing committee of the I958 Hibiscus Festival; the new secretary of the Fiji Visitors Bureau from I959 to I 963 was one of the founders of the Jaycees in 1956 and continuously on the board of the Hibiscus Festival Association in the I960s; finally, the chairman of the Fiji Visitors Bureau from I 957 to I 966 was also, apart from being mayor of Suva from I959 to I966, president of the Hibiscus Festival Association (Fiji Times; Tudor 
I968). The bureau also sponsored competitions for festival posters and financed their printing and distribution. The government supported the festival in 196I by giving a grant for extra staff to enable the Fiji Visitors Bureau to organize the festival. However, in 1962 the government considerably increased its grant for the overall running of the bureau and gave no money specifically for the organization of the festival. The Hibiscus Festival Association argued that the grant was included in the increase, which the bureau denied, and from then onward the association paid the bureau a sum for the organization of the festival. In 1966, the board of the bureau rejected that year's request from the association to organize the Hibiscus Festival. Other festivals that had come up in the meantime could legitimately expect assistance similar to that given to the Hibiscus Festival, and the bureau considered support for all of them beyond its capability. From then on, the Fiji Visitors Bureau agreed to sponsor only the festival poster competition and the distribution of the winning poster.

Despite the support and close relations between organizers of the festival, the Fiji Visitors Bureau, and the Suva City Council, the festival remained dependent on broad public support. With the wide range of events included in the festival, volunteers were essential: the ethnic nights and the different competitions and performances, without which the festival would have been an empty shell, presupposed the support of various associations and people. The queens' contests especially demanded civil support: to get contestants it was necessary to convince businesses to sponsor their dresses, auxiliaries, and a float for the final procession. Backing was there, however, and the number of contestants varied between 16 and 35. With the introduction of the Miss Charity contest, sponsorship involved the sponsors' entire personnel, because they would be expected to raise money for 'their' contestant.

By 1970, the concept of the Miss Hibiscus quest was well established in public life, and a Miss Independence quest became part of the independence celebrations. Judging procedures were similar to those of the Miss Hibiscus contest, and the winner, who was Miss University 1970 and third in the Miss Hibiscus contest of the same year, was crowned at Albert Park by the highest indigenous Fijian chief, Ratu Edward Cakobau, and congratulated by Prince Charles, who was in Fiji for the independence celebrations (Fiji Times, I 2 Oct I970). In the late I960s and early I970s, festivals with marches of youth, queen contests, processions of floats, and trips as first prize proliferated all over Fiji. Prime Minister Ratu Sir Kamisese Mara regarded these festivals as "among the attractions that 
brought visitors to Fiji and boosted the tourist industry" (Fiji Times, 3 Mar I97I). The deputy speaker of Parliament spoke with slight irritation of the "festival mania" that had conquered Fiji in a speech that was broadcast throughout the country by radio (Fiji Times, I Dec I972).

\section{Formal AND Informal National IdENTity}

The emergence and success of the Hibiscus Festival resulted from the changes in Fiji outlined earlier: the growth of Suva created a new urban public in which people, more often than previously, had to relate to others through their shared residence and citizenship rather than through relations of kinship or neighborhood. The expansion of the mass media had a similar effect of enhancing a space for public debate where people had to relate as citizens, in contrast to the distribution of information and debates in the local forums of family, neighborhood, and village. Together with the dissolution of official ethnic segregation in the public sphere, these two developments provided the basis for the emergence of a generalized public that could engage in a big, public event like the Hibiscus Festival, a development that was not confined to Suva. When the Jaycees initiated the Hibiscus Festival, the preconditions were already present, and support was plentiful from the Fiji Visitors Bureau, the government, and the tourist industry, all of which had obvious interests in furthering the growth of tourism to Fiji.

An important factor in the government's interest in the Hibiscus Festival was its multicultural character. As a result of its own policies, the colonial state was in a situation where cooperation between indigenous Fijians and Indo-Fijians was essential: the sugar industry was the backbone of the economy and depended on the cultivation of sugar mainly by Indo-Fijian farmers, who had to rent land from the indigenous Fijians, who owned 83 percent of all land but were mostly subsistence farmers. "The contradictions of colonial policy created the problem of bridging different socio-economic systems, and making the resources of one system available to the other without producing political disequilibrium. This was always the central problem for the colonial state, and it remains the problem of the national state" (Norton I986, 66-67).

The colonial government simultaneously strengthened ethnic separation and urged interethnic cooperation. Moves in the first direction were the establishment in I94 I of the Native Lands Trust Board, which was to administer rent of land owned by indigenous Fijians, and a reorganiza- 
tion in 1944 of the Fijian Administration, under which indigenous Fijians were governed, that meant tighter official control. Both bodies offered career opportunities for indigenous Fijian chiefs and commoners and linked these closely with the colonial state, while an Indo-Fijian elite developed in business, education, and in public administration. Moves toward cooperation were made by the colonial government's encouragement of interracial relationships. While there certainly was distrust between the two groups (see Cato 1955), such relationships were developing in the urban centers, especially Suva.

In Cession Day speeches, Commonwealth Day speeches, and the governor's address to the opening of the Legislative Council, the colonial government continuously stressed understanding, harmony, and interracialism (later called multiculturalism). ${ }^{13}$ Multiculturalism became an emblem, a characteristic of the nation of Fiji, that signified the specificity of Fiji in a world of political unrest and tourists. In a Cession Day speech in I957, Governor Garvey said,

We attract to our shores an increasing number of visitors from overseas, and the majority of those who give public utterance to their reactions seem favorably impressed with what they find. And well they may be. We can offer scenery of beauty and variety, an equable climate which, although exasperating at times, compares favorably with the climates of many other countries. We are a prosperous community to which nature has been generous; we are a varied community, rich in racial types which live in harmony. Consider Fiji against the background of the turmoil of the world and there is reason for gratitude: let it remain so. I like to think of Cession Day as Fiji's national day. It is a day on which we should reflect, not upon our individual interest nor upon the interest of the race to which we belong but upon the interests of the country of which we are citizens. (Fiji Times, I 5 Oct 1957)

The different ethnic groups in Fiji fought politically heated debates but did not resort to violence, and Fiji could be represented to its citizens, the outside world, and tourists as an example of "races" living in harmony and unity. In this way the formative event of the state of Fiji-the Deed of Cession-citizenship, different ethnic groups, and international tourism could be intertwined.

The emphasis on multiculturalism became stronger in the I960s, when the move toward independence accelerated, and, in preparation for the I966 elections, the leaders of the indigenous Fijians were strongly encouraged to form political parties on a multiracial basis (see Alley 1986; Lal 
I992, I97). Another example of the entanglement of multicultural harmony and tourism could be seen at the Fiji Tourism Convention in I969, where the then governor, Sir Robert Foster, described four key ingredients to continued development of the tourist industry: "The first was stable government, which pre-supposed a continuation of inter-racial harmony. Another was the recognition by the industry that the financial benefits of tourism needed to be distributed fairly evenly among all sections of the community. It was also essential that the Government should continue its rigorous support for the tourist industry. . . Finally the traditional image of Fiji as a place of smiling welcomes needed to be preserved" (Fiji Times, 23 Oct 1969).

Equal representation of the ethnic groups in the festival's organization and at its events was an explicit aim of the Suva Jaycees and later the Hibiscus Festival Association. In the 1959 festival program, Governor Sir Ronald Garvey pointed to exactly these aims in his praise of the festival: "Fijians, Indians, Europeans and Chinese are all contributing to it, providing events which represent the characteristics of each race and the unity of the whole" (Fiji Times, 23 Sep r959). In the r961 program, Governor (now Sir) Kenneth Maddocks, wrote:

As the hibiscus is the floral symbol of Fiji, so is the Hibiscus Festival a symbol of the friendliness of Fiji. The festival provides a week of gaiety, spectacle and colour for our peoples in Fiji and for the tourists who visit us at this time. It also gives us valuable publicity. But it does even more; it gives the opportunity to show what can be done by multi-racial effort. It is truly multi-racial in character. Its executive committee is multi-racial. Its events are multi-racial and its audiences are multi-racial. The events include items organized by representatives of the Fijians, the Indians, the Europeans, the Chinese, Tongans, Samoans, Gilbert Islanders and others. It is the blending of all these events which gives the festival such a wide appeal and makes it so popular. (Fiji Times, I6 Sept 196I)

The opening and closing speeches by mayors of Suva, governors, and indigenous Fijian chiefs accentuated multiculturalism, unity, and cooperation in similar ways. "Festival organisers go out of their way to ensure that members of various sections are represented in the various committees and subcommittees," reported Alexander Mamak (I978, I I2), and their practice of informal multicultural nationalism could easily interlock with the official multiculturalism of the government.

The significance of the Hibiscus Festival was reinforced by the lack in 
these years of a civil, public event that could encompass all ethnic groups. Since most indigenous Fijians were Christian and most Indo-Fijians Hindu or Muslim, religious celebrations were not suitable for uniting the ethnic groups, and the only other public events of similar scale were the state celebrations of the British empire. Central features of the festival supported the linkage between tourism, multiculturalism, and conceptualizations of the nation. The ethnic nights formed a central feature where the different ethnic groups could present themselves to other ethnic groups and tourists. Within the frame of the festival, and circumscribed by the opening and closing processions, these performances made side by side were a statement on the equality of the ethnic groups and the unity of them all, in line with the government's simultaneous emphasis on ethnic separation and interethnic cooperation. The festival was staged for tourists and locals alike, and nearly all events were public shows based on the roles of both performers and spectators. It was easy for people to participate in the Hibiscus Festival, regardless of whether they were indigenous Fijians, Indo-Fijians, or tourists, in a way that would not be possible at events that demanded a more obliging engagement. ${ }^{14}$

The most central event was the Miss Hibiscus contest, and it condensed the interrelationships of nation, tourism, and multiculturalism in its own way. The contestants came from all ethnic groups, and the judging panel had an equal representation of indigenous Fijians, Indo-Fijians, and Europeans in order to make the contest ethnically neutral. The multiracialism of the contest and judges was enhanced by Miss Hibiscus representing all of Fiji, the unity of a multiracial society. She was elected by a panel of judges comprising respected citizens, which meant that she represented civil society. On her travel overseas, where she was supposed to be an ambassador of Fiji and promote tourism, Miss Hibiscus represented civil Fiji and not the state or commerce as did the brochures and campaigns organized by the Fiji Visitors Bureau and the tourist industry.

A further, though maybe speculative, twist to interrelationships of nation and tourism can be made: through Miss Hibiscus the festival creates a person who is to travel out into the world. In the I950s and I960s this was only possible for a small minority of people and not for the public in general. However, because she represented the public, in a symbolic sense Miss Hibiscus represented the ability of Fiji as a nation to produce tourists traveling out into the world. In this sense Miss Hibiscus and all the other festival queens reversed the position of Fiji from being a country serving tourists, to a country producing them. The antithetical impli- 
cations between nation building and being a tourist destination, between being a proud nation and having to serve rich tourists, could be said to be overcome by this symbolic reversal of roles.

\section{The Contested Status of the Hibiscus Festival}

The Hibiscus Festival never really became the major tourist attraction of Fiji, and its status as the primary national, civil event in Fiji was and remains contested.

As a tourist event, the Hibiscus Festival succeeded in attracting a cruise liner or two during the festival weeks from 1958 onward, but the tourists never came in thousands as was hoped. In 1967, some members of the Fiji Visitors Bureau doubted whether the Hibiscus Festival attracted tourists at all and so questioned the support of the bureau for the festival (Fiji Times, I7 May 1967). In these years the growing thousands of tourists arriving in Fiji chose to travel by plane and not by ship, reducing the significance of cruise liners to Fiji tourism. As a consequence, the center of tourism moved from Suva to the region around the international airport at Nadi, where it was sunnier and more beaches were accessible.

As the biggest event, and because it takes place in Suva, the Hibiscus Festival was and still is seen as the major festival in Fiji. The winning queens of the Labasa Festival entered the Miss Hibiscus contest in the late I950s and early I960s, indicating an implicit hierarchy of festivals, and when relay runners brought a message from the mayor of Lautoka to Miss Hibiscus at her crowning in I964, Miss Hibiscus I964 said, "it was a thrill to think that the people of Lautoka were also thinking of her on Hibiscus night and that she was crowned Miss Hibiscus not only of Suva but the whole of Fiji" (Fiji Times, 8 Oct I964). However, as the festivals of especially Lautoka and Nadi became established events, the status of the Hibiscus Festival as a national festival was contested. The attempt, through the Miss Fiji contest initiative in 1966, to establish a nationwide contest failed, and an acknowledged hierarchy among the festivals never developed.

Tensions also existed in the multiculturalism of the festival. The practice of equal representation of the ethnic groups through separate ethnic nights was simultaneously an acknowledgment of the existence of different ethnic groups and a reinforcement of their separateness. At the same time, the ceremonial of the opening and closing ceremonies tended to be dominated by indigenous Fijian cultural items and European and indige- 
nous Fijian chiefs as speakers: some ethnic groups were more equal than others. Likewise, some social groups were more at the center of events than others: going through lists of contestants, organizers and "good citizens" on the panel of judges is almost like reading a Who's Who of upper Fijian society. Thus, in the Hibiscus Festival, just as in national politics, an imagining of the nation as multicultural competed with one that saw the indigenous Fijians at the core of the nation.

However, suggestions made by an indigenous Fijian member of the Legislative Council in 1960 and 1961 to have the Hibiscus Festival coincide with Cession Day celebrations (Fiji Times, I I Feb I96I) and suggestions made by the Fiji Times to rename Miss Hibiscus Adi Senitoa (29 Sep 1958; I5 Aug 1961), the indigenous Fijian terms for lady and the hibiscus flower respectively, were unsuccessful. Both suggestions would have the festival a mainly indigenous Fijian event, thus enhancing the narrative of the nation as indigenous Fijian at the expense of the multicultural narrative. Still, the conception of the nation promoted by people like A D Patel as founded on equal rights of citizens and a universal common roll, did not come up in the festival. The most likely place to introduce such a principle would have been at the public judgings, but the audience of these events played no role in the selection of Miss Hibiscus, which was done by the ethnically compartmentalized panel of judges. ${ }^{15}$

Finally, the ability of the Miss Hibiscus contest to produce an ambassador to represent the whole of Fiji may be questioned. A serious challenge to the representativeness of Miss Hibiscus is that out of ${ }_{5}$ Miss Hibiscus titles from I956 to I970, 9 were won by Part-Europeans, 4 by indigenous Fijians, I by a European, I by a part-Chinese, and none by an Indo-Fijian. ${ }^{16}$ It was twenty-three years after the festival's start that an Indo-Fijian Miss Hibiscus was crowned (in 1979). Notably, the PartEuropeans, "the forgotten people of Fiji," were the ones who gained most visibility through the festival. The Pacific Review, the weekly critical of colonial policies of compartmentalization, commented on the absence of an Indo-Fijian winner that the "Miss Hibiscus contest entry form demands the applicant to give her race. Probably this is contagious for beauty judgment does not require to the unprejudiced the knowledge of the race of the contestant" (Pacific Review, I7 Aug I96I). ${ }^{17}$

From a gender perspective, it is significant that the Hibiscus Festival is a competition between women in a society where males in general dominate public life, and where military and rugby, both dominated by (male) 
indigenous Fijians, as the epitome of the male virtues of loyalty and bravery, are central parts of the indigenous Fijian narrative of the nation (Howard I99I, 53-54). Whether this has had an effect on the status of the Hibiscus Festival is an open question. Although the creation of nationhood in general may be argued to be a male project (eg, Nagel I998), this does not necessarily mean that the Hibiscus Festival, as part of informal nationalism, could not work complementarily to the formal nationalism of the state.

After independence the Hibiscus Festival continued to be popular, but as the Alliance government gradually abandoned multiculturalism in the early I980s, its tight connection to the formal nationalism of the state was loosened, and with the lack of Indo-Fijian Miss Hibiscus winners, the festival's multiculturalism was less credible. The theme of tourism continued to appear in opening and closing speeches, but in its promotion campaigns the Fiji Visitors Bureau made little use of the Miss Hibiscus winners, who complained about not being asked to represent anywhere. There were allegations of misuse of money, and in 1985 the Hibiscus Festival Association declined to organize the festival, because it did not get support from the community. Subsequently, the mayor of Suva declared it his civic duty to ensure that the festival took place, and he put together a committee to organize it.

Because of the coups in 1987, the Hibiscus Festival did not take place that year, and in the following years the theme of multiculturalism was met with cynicism-especially as the military used the festival in I988 and 1989 in an attempt to gain popularity with the public by entering (indigenous Fijian) contestants. The personnel of the armed forces were all asked to voluntarily contribute part of their pay to the charity contest, and the military won the Miss Charity titles of 1988 and 1989 with the highest-ever contributions.

Multiculturalism gained in acceptance after amendments to the 1990 constitution ensuring a fairer representation of Indo-Fijians in Parliament were endorsed in 1997 as a result of a process of national reconciliation. Inspired by these developments, the Hibiscus Festival was launched under the motto Harmony-the Spirit of Hibiscus. In the positive spirit of I997, the minister of tourism declared his support for the festival in an attempt to restore it to its former prominence (Fiji Times, 30 May I997), and the Fiji Visitors Bureau also backed it and even considered launching its own contestant. In 1995, a tentative rapprochement between the festival and 
the Fiji Visitors Bureau was made when the length of festival was extended to two weeks so that its opening would coincide with the closing of the Fiji Tourism Convention, in the hope that delegates would join the festival. The initiative had little success because few delegates turned up, and there were few events to fill in the extra days. The interconnections between tourism, multiculturalism, and nation building still exist, though they do not constitute as tight a knot as in the past.

\section{Conclusion}

Whether these developments will resurrect the status the Hibiscus Festival had in the I950s and I960s remains most uncertain. In those years the multiculturalism of the festival resonated with the question, posed by urbanization, of greater non-European participation in political bodies, as well as the prospect of independence and how the different ethnic groups were to live together. The festival structure is inclusive in two ways: first, anybody can engage in its range of entertainment (games of chance, Ferris wheel, and so on) regardless of ethnic background and nationality; second, while the ethnic nights compartmentalize society into different groups, anybody can attend these as part of the audience. Indigenous Fijians, Indo-Fijians, and tourists can attend the festival in an open, voluntary, yet structured, way. Organized by a nongovernmental, nonprofit oriented association, the Hibiscus Festival can be seen as one expression of civil society's informal nationalism, whose resonance and generality in the I960s was reflected in the proliferation of similar festivals in other urban areas. Multiculturalism conceptualized the nation's diversity, while Miss Hibiscus and the other festival queens symbolized its unity. Multiculturalism and the festival queens were internal, informal expressions of nation that in these years linked neatly with the formal nationalism of both the colonial government and the Alliance party in their efforts to build a nation. Simultaneously, both multiculturalism and Miss Hibiscus were used externally to characterize the uniqueness of the nation. The Hibiscus Festival was part of an informal nationalism in civil society that connected to the formal nationalism of the state. In this process of nation building, international tourism and multiculturalism became interwoven in the festival. After independence, for instance, multiculturalism was used by Ratu Mara, the prime minister from I970 to I987, to designate the uniqueness of the nation of Fiji in international politics, and was implied in the slogan Fiji-the Way the World Should 
Be of the Fiji Visitors Bureau, which also used Miss Hibiscus in its promotional campaigns.

A resurrection of the Hibiscus Festival's status will depend, among other factors, on the credibility of both multiculturalism and Miss Hibiscus with the public - both nationally and internationally. With the new constitution, multiculturalism may again become credible in both arenas, whereas the status of Miss Hibiscus seems more uncertain: internally in Fiji, future Miss Hibiscus queens will probably have to come from a wider range of ethnic backgrounds if they are to be credible symbols of all Fiji, but even if this is achieved, they may have difficulty gaining recognition in Fiji and abroad, because beauty contests since the early I970s have lost status internationally. Neither nations nor national tourist bureaus are likely to gain much renown through beauty queens. One solution would be to downplay the notion of Miss Hibiscus as the embodiment of beauty, and instead emphasize, as already done by organizers in Fiji, a depiction of her as the incorporation of culture and tradition (but whose?), in the manner of Tonga's Miss Heilala (see Teilhet-Fisk 1996) or "custom queens" in the Solomon Islands (Geoffrey White, personal communication). Whether any of this will happen is, of course, pure speculation. What I have argued here, is that tourism is not always antithetical to national identity or nation building, but may reinforce both.

This ARTIClE WAS FIRST PRESENTED at the European Society for Oceanists' third biennial conference in Copenhagen, I3-I5 December 1996. A revised version was presented at the eighth Pacific Science Intercongress in Suva, Fiji, I3-I7 July I997. I would like to thank participants at both conferences for their comments. Jens Pinholt, Ton Otto, Robert Tonkinson, Richard Wilk, Teresia Teaiwa, and the reviewers have all made suggestions and points that have improved the original paper considerably. Finally, I am deeply indebted to the people who belped me during my stays in Fiji in 1995 and 1997.

\section{Notes}

I In Fiji, these groups are called races, and in indigenous Fijian nationalism a distinction is made between the "indigenous" and the "ethnic." Here the former are called indigenous Fijians and the term ethnic group is applied in its general anthropological sense to any collective identity based on cultural features. Thus, in this usage, "indigenous Fijians" and "Indo-Fijians" are both "ethnic groups." 
2 The Fiji Times is the only daily newspaper published continuously in the period considered here, and therefore the main source of information for what follows. Until 1956, it was owned by Alport Barker, who was also a member of the Legislative Council, chairman of the Suva Chamber of Commerce, and chairman of the Suva Town Board. It was mainly directed toward the European community, but also had an indigenous Fijian and Indo-Fijian readership. Despite Barker's critical stance toward the government, the paper was a loyal supporter of British colonialism and strongly anti-Indo-Fijian (Griffen I99I, I70-I72). In I956 the paper was bought by R W Robson who also published the Pacific Islands Monthly and was an honorary agent of the Fiji Visitors Bureau. The newspaper remained a supporter of the colonial Fijian and European establishment. Leonard Usher became executive director of the Fiji Times in 1956 and editor in 1958 . Usher had been a government public relations officer from 1943 to 1956 , a member of the Fiji Visitors Bureau from I953 to 1956, a Suva city councillor from 1962, mayor of Suva from 1967 to I970, and had close ties to the Alliance Party. An additional source of information was the Pacific Review, launched in 1949 by A D patel, who later was one of the main founders of the National Federation Party. Published weekly, it highlighted Indo-Fijian grievances and was highly critical of British colonialism.

3 For the case of Hawai'i, see Buck 1993, I63-г9r.

4 For a critical assessment of Boorstin and MacCannell, see Cohen I979.

5 For the need to get beyond "authenticity" and "commercialization" in these discussions, see Cohen 1988 .

6 These are discussed later; for examples see also Cohen and Mascia-Lees (1993), Leong (1989), and most notably Picard (1996) and the articles in Picard and Wood (I997).

7 For a similar point in the case of the Polynesian Cultural Center in Hawaici, see Ross I994, 2 I-98.

8 For further discussion of these concepts see Otto 1997; Howard I991, 54-55, I29-130; Keesing and Tonkinson 1982, respectively. For a general, barbed criticism see Babadzan 1988 .

9 For a nuanced depiction of indigenous Fijian narratives of the nation, see Rutz 1997.

Io See for example the editorials of the Fiji Times of 27 May and I9 Aug I952, I2 Dec and 6 Mar I953.

I I On state appropriation of culture and public events for nation building, see Hobsbawm and Ranger 1983.

I 2 See, for example, editorials in the Fiji Times of 28 Jan, 23 May, 30 July, 6 Sep 1956 , and 17 Dec 1957.

I 3 See, for example, the Fiji Times of 29 Oct 1958, 25 May and I 8 June I959, 9 Oct 1967, I4 Oct 1969, and I3 Oct I970. 
I 4 Victor Turner distinguished between the liminal rituals of traditional societies, where the emphasis is on obligation, and the liminoid rituals of modern societies, which are mainly voluntary $(1982,37)$. For an interesting connection between open, multi-event spectacles like the Hibiscus Festival and modernity, see MacAloon I984.

I 5 The kind of queen contests where entrants sell ticket votes might be seen as the selection of a queen by citizens of equal status, though the ability to sell votes also would depend on connection to monied people and undermine the democratic principle of the contest. Facts are, however, inconclusive: of the 4 Miss Charity Queens from 1967, when the competition was introduced in the Hibiscus Festival, to I970, I was Indo-Fijian, I Part-European, and I Rotuman (I have no data on Miss Charity I969).

I 6 A more detailed breakdown includes the number of contestants, place-getters (Miss Hibiscus, and Ist and 2nd runners-up), and Miss Hibiscus. From 1956 through I970, of 3 I 3 contestants, I 2 I Part-Europeans won 26 places and 9 Miss Hibiscus titles; 65 indigenous Fijians won 9 places and 4 Miss Hibiscus titles; 26 Europeans won 4 places and I Miss Hibiscus title; 3 part-Chinese won 2 places and I Miss Hibiscus title; and 30 Indo-Fijians won 3 places and o Miss Hibiscus titles ( 49 contestants from other groups won neither a place nor the title; I9 contestants, none of whom won a place, are unaccounted for).

I7 The Pacific Review was critical of the bias of the contest, not of the contest nor the festival as such. For critical remarks, see Pacific Review, I9 Sep I963, 27 Sep and 8 Oct I968, 6 Sep, I3 Sep, and 20 Sep I973.

\section{References}

Alley, Roderic

I986 The Emergence of Party Politics. In Politics in Fiji, by Brij V Lal, 28-5I. Sydney: Allen \& Unwin.

Anderson, Benedict

I99I Imagined Communities. London: Verso.

Babadzan, Alain

I988 Kastom and Nation Building in the South Pacific. In Ethnicities and Nations: Processes of Interethnic Relations in Latin America, Southeast Asia, and the Pacific, edited by R Guidieri, F Pellizi, and S J Tambiah, I99-228. Austin: University of Texas Press.

Banner, Louis

I983 American Beauty. New York: Alfred Knopf.

Boorstin, Daniel

I96I The Image: A Guide to Pseudo-Events in America. New York: Harper \& Row. 
Britton, Stephen G

I983 Tourism and Underdevelopment in Fiji. Development Studies Centre Monograph 3 I. Canberra: Australian National University.

Buck, Elizabeth

I993 Paradise Remade: The Politics of Culture and History in Hawai' $i$. Philadelphia: Temple University Press.

Cato, A C

I995 Fiji and Fiji Indians: A Culture-Contact Problem in the South Pacific. Oceania 26 (I): I4-34.

Cohen, Colleen B, and Frances E Mascia-Lees

I993 The British Virgin Islands as Nation and Desti-nation: Representing and Siting Identity in a Post-colonial Caribbean. Social Analysis 33: I30-I 5 I.

Cohen, Colleen B, Richard Wilk, and Beverly Stoeltje

I996 Introduction: Beauty Queens on the Global Stage. In Beauty Queens on the Global Stage: Gender, Contests, and Power, edited by Colleen B Cohen, Richard Wilk, and Beverly Stoeltje, I-I2. London and New York: Routledge.

Cohen, Eric

I972 Towards a Sociology of Tourism. Social Research 39 (I): I64-I82.

I979 Rethinking the Sociology of Tourism. Annals of Tourism Research 6 (Jan-Mar): I 8-35.

I988 Authenticity and Commodization in Tourism. Annals of Tourism Research I 5 (3): 37I-386.

Eriksen, Erik H

I993 Formal and Informal Nationalism. Ethnic and Racial Studies I6 (I): I-25.

Foster, Robert J, editor

I995a Nation Making: Emergent Identities in Postcolonial Melanesia. Ann Arbor: University of Michigan Press.

I995b Print Advertisements and Nation Making in Metropolitan Papua New Guinea. In Nation Making: Emergent Identities in Postcolonial Melanesia, edited by Robert J Foster, I5I-I8I. Ann Arbor: University of Michigan Press.

Graburn, Nelson H

I976 Ethnic and Tourist Art: Cultural Expressions from the Fourth World. Berkeley: University of California Press.

Griffen, Vanessa

I99I Control of the Press and Information in the British Colonies I939-I955, with a Case Study of Fiji. PhD dissertation, University of the South Pacific, Suva. 
Hobsbawm, Eric, and Terence Ranger, editors

I983 The Invention of Tradition. Cambridge: Cambridge University Press.

Howard, Michael

I99I Fiji: Race and Politics in an Island State. Vancouver: University of British Columbia Press.

Keesing, Roger M, and Robert Tonkinson, editors

1982 Reinventing Traditional Culture: The Politics of Kastom in Island Melanesia. Mankind I3(4). Special issue.

Lal, Brij V

I992 Broken Waves: A History of the Fiji Islands in the Twentieth Century. Pacific Islands Monograph Series I I. Honolulu: University of Hawai'i Press.

Lavenda, Robert $\mathrm{H}$

I996 "It's Not a Beauty Pageant!" Hybrid Ideology in Minnesota Community Queen Pageants. In Beauty Queens on the Global Stage: Gender, Contests, and Power, edited by Colleen B Cohen, Richard Wilk, and Beverly Stoeltje, $3 \mathrm{I}-46$. London and New York: Routledge.

Leong, Wai-Teng L

I989 Culture and the State: Manufaturing Traditions for Tourism. Critical Studies in Mass Communication 6 (Dec): 355-375.

Löfgren, Orvar I989 The Nationalization of Culture. Ethnologia Europaea I9 (I): 5-24.

MacAloon, John

I984 Olympic Games and the Theory of Spectacle in Modern Society. In Rite, Drama, Festival, Spectacle, edited by John MacAloon, 24I-280. Philadelphia: University of Pennsylvania Press.

MacCannell, Dean

1973 Staged Authenticity: Arrangements of Social Space in Tourist Settings. American Journal of Sociology 79 (3): 589-603.

I976 The Tourist: A New Theory of the Leisure Class. New York: Shocken Books.

Mamak, Alexander F

I978 Colour, Culture and Conflict: A Study of Pluralism in Fiji. Sydney: Pergamon Press.

Manning, Frank E

I978 Carnival in Antigua (Caribbean Sea): An Indigenous Festival in a Tourist Economy. Anthropos 73 (I-2): I9I-204.

Nagel, Joane

I998 Masculinity and Nationalism: Gender and Sexuality in the Making of Nations. Ethnic and Racial Studies 2I (2): 242-269. 
Nettekoven, Lothar

I979 Mechanisms of Intercultural Interaction. In Tourism. Passport to Development, edited by Emanual de Kadt, I35-I45. New York: Oxford University Press.

Norton, Robert

I986 Colonial Fiji: Ethnic Divisions and Elite Conciliation. In Politics in Fiji, edited by Brij V Lal, 52-73. Sydney: Allen \& Unwin.

I990 Race and Politics in Fiji. Second edition. St Lucia: University of Queensland Press.

Otto, Ton

I997 After the "Tidal Wave": Bernard Narokobi and the Creation of a Melanesian Way. In Narratives of Nation in the South Pacific, edited by Ton Otto and Nicholas Thomas, 33-64. Amsterdam: Harwood Academic Publishers.

Otto, Ton, and Nicholas Thomas, editors

I997 Narratives of Nation in the South Pacific. Amsterdam, Harwood Academic Publishers.

Otto, Ton, and Robert J Verloop

I996 The Asaro Mudmen: Local Property, Public Culture? The Contemporary Pacific 8:349-386.

Pacific Review. Weekly. Suva.

Picard, Michel

I996 Bali: Cultural Tourism and Touristic Culture. Singapore: Archipelago Press.

Picard, Michel, and Robert E Wood, editors

I997 Tourism, Ethnicity, and the State in Asian and Pacific Societies. Honolulu: University of Hawai'i Press.

Qalo, Ropate R

I984 Divided We Stand? Local Government in Fiji. Suva: Institute of Pacific Studies, University of the South Pacific.

Ross, Andrew

I994 The Chicago Gangster Theory of Life: Nature's Debt to Society. London and New York: Verso.

Rutz, Henry J

I997 Occupying the Headwaters of Tradition: Rhetorical Strategies of Nation Making in Fiji. In Nation Making: Emergent Identities in Postcolonial Melanesia, edited by Robert J Foster, 7I-94. Ann Arbor: University of Michigan Press.

Sissons, Jeffrey

I997 Nation or Desti-nation? Cook Islands Nationalism since I965. In Narratives of Nation in the South Pacific, edited by Ton Otto and Nicholas Thomas, I63-I 88. Amsterdam: Harwood Academic Publishers. 
Smith, Valene L

I978 Host and Guests: The Anthropology of Tourism. Oxford: Blackwell.

sHCA, Suva Hibiscus Carnival Association

I995 Hibiscus Carnival Souvenir Programme. Suva: Hibiscus Carnival Association

Teilhet-Fisk, Jehanne

I996 The Miss Heilala Beauty Pageant: Where Beauty Is More Than Skin Deep. In Beauty Queens on the Global Stage: Gender, Contests, and Power, edited by Colleen B Cohen, Richard Wilk, and Beverly Stoeltje, I 85-202. London and New York: Routledge.

Thomas, Nicholas

I997 Nations' Endings: From Citizenship to Shopping? In Narratives of Nation in the South Pacific, edited by Ton Otto and Nicholas Thomas, 2 I I-220. Amsterdam: Harwood Academic Publishers.

Tudor, Judy, editor

I968 Pacific Islands Year Book and Who's Who. Sydney: Pacific Publications.

Turner, Victor

I982 From Ritual to Theatre. New York.

Urry, John

I990 The Tourism Gaze: Leisure and Travel in Contemporary Societies. London: Sage.

Wilk, Richard

I996 Connections and Contradictions: From the Crooked Tree Cashew Queen to Miss World Belize. In Beauty Queens on the Global Stage: Gender, Contests, and Power, edited by Colleen B Cohen, Richard Wilk, and Beverly Stoeltje, 2I7-232. London and New York: Routledge.

Williams, Brackette

I989 A Class Act: Anthropology and the Race to Nation Across Ethnic Terrain. Annual Review of Anthropology I 8:40I-444.

Wood, Robert E

I980 International Tourism and Cultural Change in Southeast Asia. Economic Development and Cultural Change 28 (3): 56I-58I.

I984 Ethnic Tourism, the State, and Cultural Change in Southeast Asia. Annals of Tourism Research I I (3): 353-374.

\section{Abstract}

Why did festivals proliferate in all urban centers in Fiji in the late I950s and I960s to the extent that one official talked about "festival mania"? Today the Hibiscus Festival in Suva, the Sugar Festival in Lautoka, the Bula Festival in 
Nadi, and various other festivals have become natural parts of the national culture. However, when the festivals were started they were constructed as tourist attractions that should lure tourists to Fiji. Thus, the development of the festivals from being constructed tourist events to become part of the national culture points to some of the unexpected ways in which tourism links up with national identity. From 1950 to independence in 1970 three parallel processes of change took place in Fiji: Tourism became a major industry thus alleviating the economic dependence on sugar-production, urbanization created a new urban space for social interaction and public discussion, and a national identity had to be created as it became apparent that Fiji would cease to be a British colony and become independent. In this paper I will discuss how these processes of change condensed into "festival mania" focusing on the years from 1950 to independence in 1970.

KEYWORDS: festivals, Fiji, national identity, tourism 